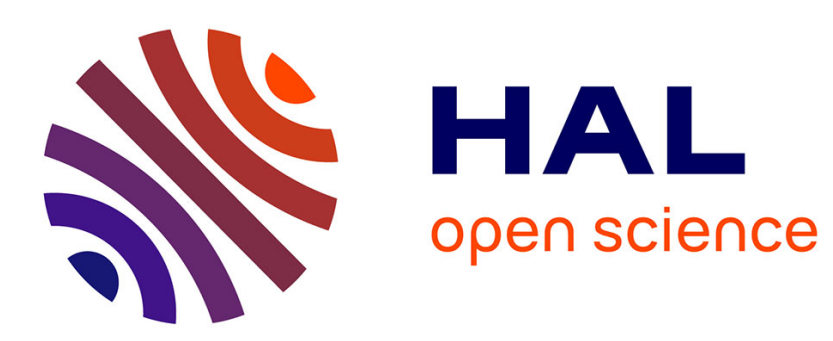

\title{
Ca2+ oscillations and the cell cycle at fertilisation of mammalian and ascidian eggs
}

\author{
Victoria L Nixon, Alex Mcdougall, Keith T Jones
}

\section{To cite this version:}

Victoria L Nixon, Alex Mcdougall, Keith T Jones. Ca2+ oscillations and the cell cycle at fertilisation of mammalian and ascidian eggs. Biology of the Cell, 2000, 92 (3-4), pp.187-196. 10.1016/s02484900(00)01068-6 . hal-03025745

\section{HAL Id: hal-03025745 \\ https://hal.science/hal-03025745}

Submitted on 16 Dec 2020

HAL is a multi-disciplinary open access archive for the deposit and dissemination of scientific research documents, whether they are published or not. The documents may come from teaching and research institutions in France or abroad, or from public or private research centers.
L'archive ouverte pluridisciplinaire HAL, est destinée au dépôt et à la diffusion de documents scientifiques de niveau recherche, publiés ou non, émanant des établissements d'enseignement et de recherche français ou étrangers, des laboratoires publics ou privés. 


\title{
$\mathrm{Ca}^{2+}$ oscillations and the cell cycle at fertilisation of mammalian and ascidian eggs
}

\author{
Victoria L. Nixon", Alex McDougall, Keith T. Jones
}

Department of Physiological Sciences, The Medical School, Framlington Place, University of Newcastle-uponTyne, Newcastle NE2 4HH, UK

Received 16 February 2000; accepted 10 April 2000

At fertilisation of mammalian and ascidian eggs the sperm induces a series of $\mathrm{Ca}^{2+}$ oscillations. These $\mathrm{Ca}^{2+}$ oscillations are triggered by a sperm-borne $\mathrm{Ca}^{2+}$-releasing factor whose identity is still unresolved. In both mammals and ascidians $\mathrm{Ca}^{2+}$ oscillations in eggs are associated with the period leading up to exit from meiosis and entry into the first embryonic cell cycle. Thus, in mammals $\mathrm{Ca}^{2+}$ oscillations continue for several hours but are complete by within $30 \mathrm{~min}$ in the ascidian. In mammals and ascidians $\mathrm{Ca}^{2+}$ oscillations stop at around the time when pronuclei form in the 1-cell embryo. There is evidence to show that cell cycle factors are important in regulating the fertilisation $\mathrm{Ca}^{2+}$ signal. If the formation of pronuclei is blocked either in mammals (by spindle disruption) or in ascidians (by clamping maturation promoting factor levels high) then $\mathrm{Ca}^{2+}$ oscillations continue indefinitely. Here, we explore the nature of the sperm $\mathrm{Ca}^{2+}$-releasing factor and examine the relationship between cell cycle resumption and the control of $\mathrm{Ca}^{2+}$ oscillations at fertilisation.

(C) 2000 Éditions scientifiques et médicales Elsevier SAS

\section{egg / fertilisation / cell cycle / calcium}

\section{INTRODUCTION}

The process of fertilisation is initiated by gamete fusion and can be considered to include all the events associated with egg activation until the time when the egg is committed to embryonic development. For nearly all species it is a rise in the cytosolic free $\mathrm{Ca}^{2+}$ concentration that acts as the trigger for the events associated with fertilisation.

In most species the egg arrests during meiosis before fertilisation. Notable exceptions include sea urchin, which completes meiosis before arresting, and starfish, which does not seem to show any arrest at all at the time the eggs are normally fertilised (for review see Whitaker, 1996). For this review we will concentrate on

\footnotetext{
*Correspondence and reprints: v.l.nixon@ncl.ac.uk
}

mammals, specifically mouse and hamster, where most of the experimental work has been performed, and ascidians. Mammalian and ascidian eggs share many similarities; both arrest at metaphase, mammalian eggs arrest at metaphase of the second meiotic division (MII), while ascidian eggs arrest at metaphase of the first meiotic division (MI). They also both show a series of $\mathrm{Ca}^{2+}$ oscillations when fertilised, rather than a single $\mathrm{Ca}^{2+}$ transient. For the purposes of this review we will define 'egg' as the female gamete at the time it is normally fertilised. Neither mammalian nor ascidian eggs have completed meiosis at the time of fertilisation and therefore should strictly be called oocytes rather than eggs.

In this review we will try to address how the sperm triggers $\mathrm{Ca}^{2+}$ oscillations at fertilisation and how the egg regulates these $\mathrm{Ca}^{2+}$ oscillations. Our main hypothesis is that a $\mathrm{Ca}^{2+}$-releasing factor in sperm induces egg 
activation and this factor is regulated by events in the cell cycle. Thus $\mathrm{Ca}^{2+}$ oscillations stop when they are no longer needed, when the egg has become committed to embryonic development.

\section{THE SPATIOTEMPORAL ASPECTS OF THE $\mathrm{CA}^{2+}$ SIGNAL AT FERTILISATION}

A sperm-induced increase in the egg intracellular $\mathrm{Ca}^{2+}$ concentration was first observed in medaka eggs over 20 years ago (Ridgway et al., 1977). Such an increase has since been found in nearly every animal species and even during fertilisation of species in the plant kingdom (Digonnet et al., 1997).

The precise temporal dynamics of the $\mathrm{Ca}^{2+}$ signal in the egg at fertilisation varies between species. In medaka (Ridgway et al., 1977), sea urchin (Steinhardt et al., 1977) and frog (Busa and Nuccitelli, 1985) $\mathrm{Ca}^{2+}$ propagates as a single wave, originating from the point of sperm entry. However, in mammalian eggs the initial wave of $\mathrm{Ca}^{2+}$, which also propagates from the point of sperm fusion (Miyazaki et al., 1986), is followed by a long-lasting series of $\mathrm{Ca}^{2+}$ oscillations (Miyazaki and Igusa, 1981; Cuthbertson and Cobbold, 1985). This has been documented in murine (Cuthbertson and Cobbold, 1985), hamster (Miyazaki et al., 1986), bovine (Fissore et al., 1992), porcine (Sun et al., 1992), rabbit (Fissore and Robl, 1993), rat (Ben-Yosef et al., 1993) and human (Taylor et al., 1993). Such $\mathrm{Ca}^{2+}$ oscillations last for several hours (figure 1a). In ascidians the sperm-induced $\mathrm{Ca}^{2+}$ signal is also initiated from the point of sperm fusion (Speksnijder et al., 1989a). The sperm generates a series of $\mathrm{Ca}^{2+}$ oscillations that last for about $30 \mathrm{~min}$ (Speksnijder et al., 1989b). Intriguingly the pattern of $\mathrm{Ca}^{2+}$ release is composed of two distinct phases of oscillations separated by a gap period (figure 1b). The gap period corresponds to when the first polar body is extruded.

Some 'variations' on the above 'theme' (that sperm induce a $\mathrm{Ca}^{2+}$ rise) have been observed in a number of animal eggs. For example in zebrafish, the increase in $\mathrm{Ca}^{2+}$ occurs before fusion with the sperm, when the egg is released into freshwater (Lee et al., 1999). In the shrimp (Sicyonia ingentis) and prawn (Palaemon serratus) $\mathrm{Mg}^{2+}$ in the seawater acts to raise intracellular $\mathrm{Ca}^{2+}$ (Lindsay et al., 1992; Goudeau and Goudeau, 1996). However, in the prawn, sperm trigger an additional calcium signal at fertilisation (Lindsay et al., 1992). Such activations are certainly worthy of study, but should not distract from the more general finding that it is only the sperm that raises intracellular $\mathrm{Ca}^{2+}$ following gamete fusion.

\section{a. mouse fertilisation}

60 minutes

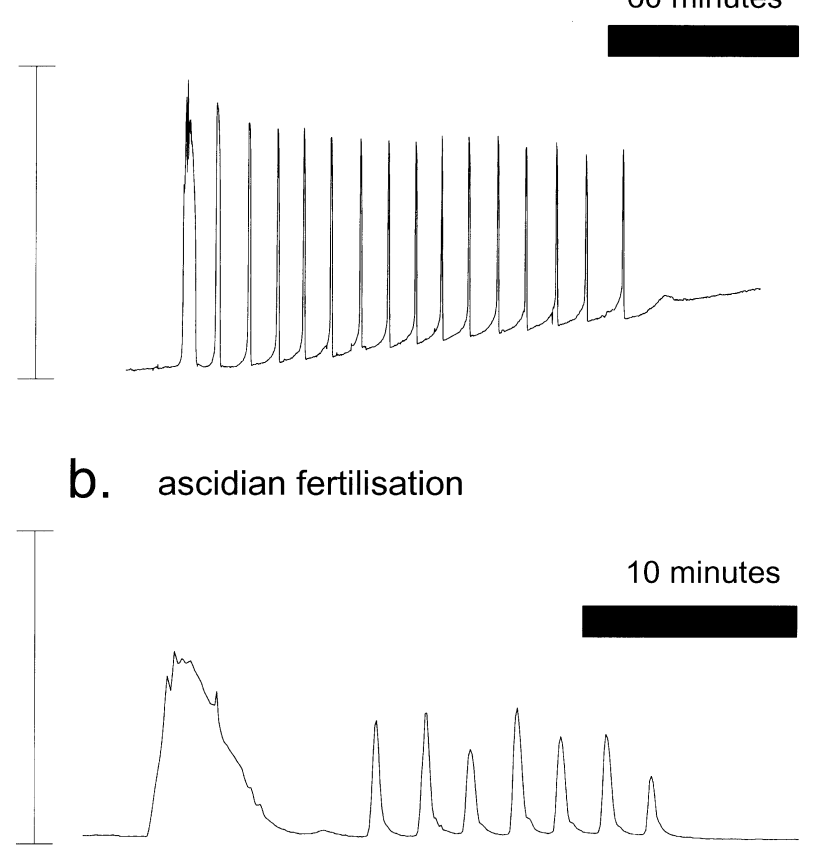

Figure 1. Fertilisation in mammalian and ascidian eggs. Fertilisation of MF1 mouse eggs (a) results in a long-lasting series of $\mathrm{Ca}^{2+}$ oscillations that stop about the time when pronuclei form in the developing embryo. The $\mathrm{Ca}^{2+}$ oscillations associated with fertilisation of ascidian (Ascidiella aspersa) eggs occur over a much shorter timeframe (note different timescale in $\mathbf{a}$ and $\mathbf{b}$ ) In ascidians the $\mathrm{Ca}^{2+}$ oscillations consist of two phases separated by a gap period that corresponds to extrusion of the first polar body. In both eggs $\mathrm{Ca}^{2+}$ is recorded using Fura2, for details of $\mathrm{Ca}^{2+}$ recording see Levasseur and McDougall (2000). y-axis is 1 ratio unit (see Levasseur and McDougall, 2000).

\section{FUNCTION OF $\mathrm{CA}^{2+}$ AT FERTILISATION}

All the events associated with fertilisation in mouse are either inhibited by buffering $\mathrm{Ca}^{2+}$ action (Kline and Kline, 1992) or induced by microinjecting $\mathrm{Ca}^{2+}$ into eggs (Fulton and Whittingham, 1978). These events include cortical granule (CG) exocytosis, essential for preventing polyspermy (Kline and Kline, 1992; Ducibella et al., 1993; Xu et al., 1994), and meiotic resumption (reviewed in Whitaker, 1996; Jones, 1998). The exact signal transduction pathways involved in CG release and meiotic resumption remain to be fully understood. Temporally CG release occurs quickly, as would be physiologically expected, while meiotic resumption takes a few hours to complete. This has led to the suggestion of 'early' and 'late' events of egg activation (Xu et al., 1994). In ascidian there is no CG release but polyspermy can be inhibited by two other 
mechanisms. There is a fast electrical block whereby positive membrane potentials block sperm-egg fusion (Goudeau et al., 1994). This is followed by a slower block to sperm-egg binding, associated with the release of an egg and follicular cell surface N-acetyl glucosaminadase (Lambert, 1989; Robert et al., 1999) in a $\mathrm{Ca}^{2+}$-dependent manner (McDougall et al., 1995). However, in ascidian, like mammals, the $\mathrm{Ca}^{2+}$ oscillations are involved in inducing meiotic maturation (McDougall and Sardet, 1995; Arnoult et al., 1996; Russo et al., 1996; Yoshida et al., 1998).

For eggs which arrest at metaphase II (and likely MI also), meiotic arrest is achieved through the concerted action of maturation (or M-phase) promoting factor (MPF) and cytostatic factor (CSF). MPF is a universal trigger for entry from interphase into mitosis/meiosis (Nurse, 1990). MPF was first described in the amphibian by its ability to trigger oocyte maturation (Masui and Markert, 1971; Smith and Ecker, 1971) and was later identified as being composed of a regulatory component, cyclin B (Evans et al., 1983; Labbe et al., 1989), and a homologue of the fission yeast protein p34 $4^{\text {cdc2 }}$ (Nurse and Thuriaux, 1980). A flurry of interest in 1988 convincingly demonstrated that the catalytic component of MPF was p34 ${ }^{\mathrm{cdc} 2}$, now renamed CDK1 for cyclin-dependent kinase (Dunphy et al., 1988; Gautier et al., 1988; Lohka et al., 1988; see review by Morgan, 1997). MPF is inactivated by polyubiquitination of its cyclin B component, which targets it for destruction (Murray et al., 1989). However, in eggs MPF activity is stabilised by a cytostatic factor (CSF), such that cell cycle arrest is achieved before fertilisation. CSF was first defined by its ability to trigger metaphase arrest when injected into blastomeres of developing embryos (Masui and Market, 1971; Masui, 1974). It is now generally regarded that the product of the c-mos gene has CSF activity (reviewed by Masui, 1991; Sagata, 1997). Consistent with this, mice with a c-mos knockout fail to arrest in MII and parthenogenetically activate (Colledge et al., 1994; Hashimoto et al., 1994). However, unlike MPF, the components of CSF are still not fully determined (Ciemerych and Kubiak, 1999).

The signal transduction pathway from the $\mathrm{Ca}^{2+}$ signal to meiotic resumption in the frog egg involves calmodulin-dependent protein kinase II (CaMKII). CaMKII induces ubiquitin-dependent degradation of the MPF cyclin B component (Lorca et al., 1993), targeting it for proteolysis by the proteasome. Evidence now exists that CaMKII is also activated in mammals by a $\mathrm{Ca}^{2+}$ rise (Winston and Maro, 1995; Tatone et al., 1999) and a CaMKII inhibitor can block meiotic resumption but not cortical granule release of mouse eggs (Inagaki et al., 1997). The involvement of $\mathrm{Ca}^{2+}$ in meiotic resumption is sketched in figure 2. It is clear that many of the exact details still need to be examined

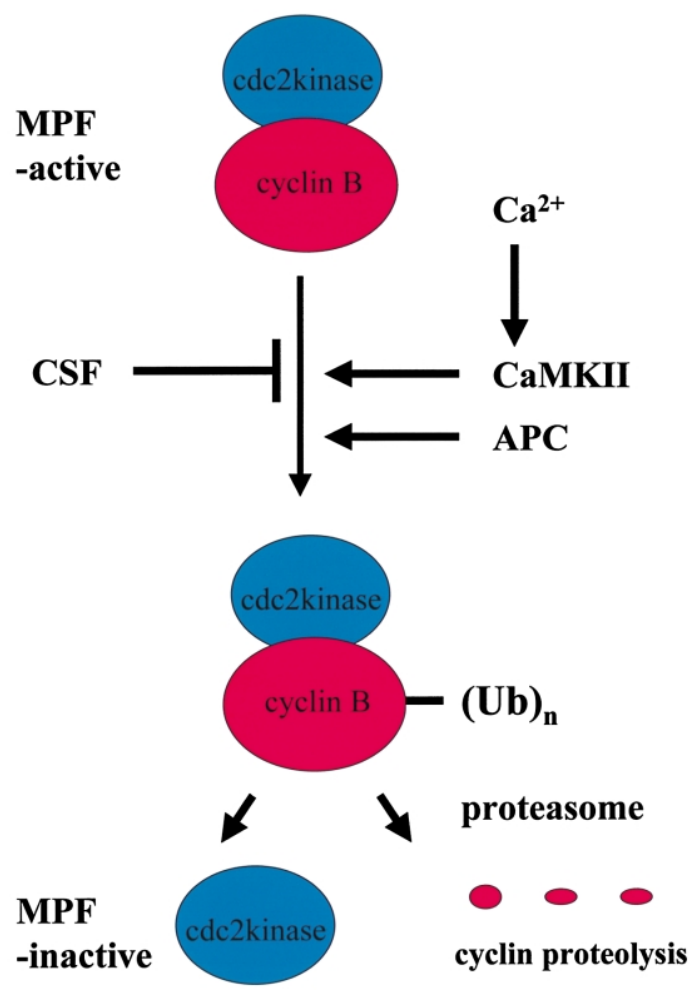

Figure 2. Interaction of the $\mathrm{Ca}^{2+}$ signal at fertilisation with CSF and MPF. MPF activity is clamped high before fertilisation by the presence of CSF. MPF is known to be composed of a catalytic cdc2 kinase subunit and a regulatory cyclin B subunit. Cyclin B is polyubiquitinated $(\mathrm{Ub})_{\mathrm{n}}$ by the anaphase promoting complex (APC), a ubiquitin ligase. This ubiquitination targets it for destruction by the proteasome. However, in eggs this is prevented by CSF, a factor whose exact identity is not fully resolved. The product of the c-mos gene has CSF activity and c-mos is believed to have MAP kinase kinase kinase activity, implicating the MAP kinase pathway in CSF-induced egg arrest. In both amphibians and mouse, activation of MPF destruction by $\mathrm{Ca}^{2+}$ has been shown to be mediated by CaMKII. The precise signalling pathway that involves CaMKII is not known. Neither is the mechanism by which CSF is degraded.

since our knowledge of the actual pathways involved is rudimentary.

\section{THE MECHANISM RESPONSIBLE FOR THE $\mathrm{CA}^{2+}$ TRANSIENTS}

Knowledge of the mechanism employed by the sperm to trigger $\mathrm{Ca}^{2+}$ transients is also important for our understanding of fertilisation. The precise mechanism operating for any species is unknown but we will consider the models in terms of the 'conduit', 'contact' and 'content' models as first coined by Jaffe (1991). 
In the 'conduit' model the sperm acts as a conduit for $\mathrm{Ca}^{2+}$ entry from the extracellular medium. Alternatively, the source of the $\mathrm{Ca}^{2+}$ could be the sperm itself, the so-called ' $\mathrm{Ca}^{2+}$ bomb' hypothesis. $\mathrm{Ca}^{2+}$ entry would overload intracellular stores and so induce $\mathrm{Ca}^{2+}$ release. Such a phenomenon of $\mathrm{Ca}^{2+}$ influx causing store overload has been proposed to occur in the sea urchin egg at fertilisation (Creton and Jaffe, 1995) and in muscle cells (Fabiato, 1985; Wier and Blatter, 1991). In support of this model, it is well known that extracellular $\mathrm{Ca}^{2+}$ is needed for the maintenance of oscillations in the mouse egg (McGuinness et al., 1996) and that blocking the influx of the $\mathrm{Ca}^{2+}$ results in inhibition of the oscillations (e.g., Igusa and Miyazaki, 1983). However, the influx of $\mathrm{Ca}^{2+}$ is associated with capacitative $\mathrm{Ca}^{2+}$ influx following a $\mathrm{Ca}^{2+}$ transient, rather than initiating it (McGuinness et al., 1996). Furthermore, direct measurement of sperm and egg $\mathrm{Ca}^{2+}$ levels in the region of gamete fusion failed to detect any evidence of $\mathrm{a} \mathrm{Ca}^{2+}$ influx from the fertilising sperm (Jones et al., 1998a). Finally, the sperm-triggered calcium oscillations all appear to be waves that originate in the vegetal hemisphere of the oocyte irrespective of the site of sperm-egg fusion (Kline et al., 1999; Deguchi et al., 2000). Therefore, in mammals at least, this model appears untenable.

The second model proposes that 'contact' between a sperm ligand and an egg receptor induces activation of an egg phospholipase C (PLC) (Foltz and Shilling, 1993; Evans and Kopf, 1998). This model predicts that the second messenger inositol 1,4,5-trisphosphate $\left(\mathrm{InsP}_{3}\right)$, produced by egg PLC hydrolysis of phosphatidylinositol 4-, 5-bisphosphate, would be responsible for $\mathrm{Ca}^{2+}$ oscillations. There is very strong experimental evidence for this model in mammals. Much of the signal transduction pathway necessary in this model is present and functions in mammalian eggs. $\mathrm{InsP}_{3}$ can induce $\mathrm{Ca}^{2+}$ oscillations in both mouse and hamster oocytes (Swann et al., 1989, Swann, 1994; Jones and Whittingham, 1996). Furthermore, methods to block this pathway invariably block fertilisation. For example, the fertilisation-dependent $\mathrm{Ca}^{2+}$ increase in hamster and mouse eggs is blocked by a functionally inhibitory antibody to the type $1 \mathrm{InsP}_{3}$ receptor (Miyazaki et al., 1992, 1993), which is the predominant receptor isoform in mammalian eggs (Parrington et al., 1998; He et al., 1999). In addition the PLC inhibitor U73122 blocks $\mathrm{Ca}^{2+}$ oscillations in mouse (Dupont et al., 1996). Despite this evidence, no reported sperm ligand or egg receptor has been identified to cause $\mathrm{Ca}^{2+}$ changes in mammalian eggs. In fact, so far, molecules believed to be important in gamete binding and fusion do not seem to be involved in triggering egg activation and hence $\mathrm{Ca}^{2+}$ release (Cho et al., 1998; LeNaour et al., 2000; Miyado et al., 2000).

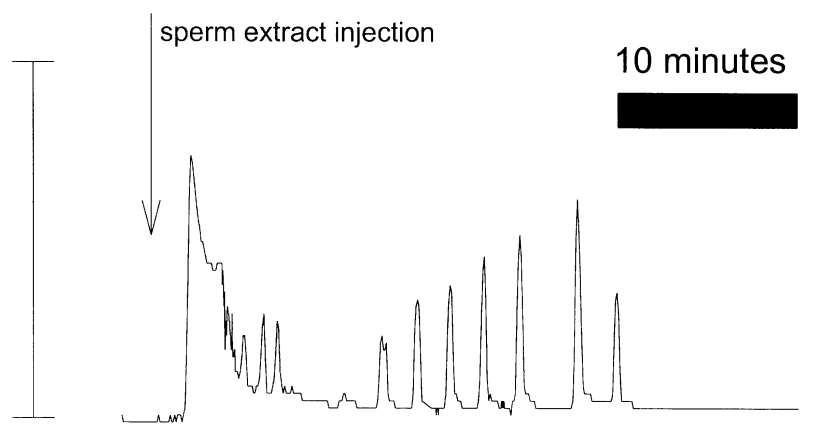

Figure 3. Sperm extract microinjection into ascidian eggs mimics the $\mathrm{Ca}^{2+}$ oscillations seen at fertilisation. Ascidian sperm extract $(7.8 \mathrm{mg} / \mathrm{mL})$ microinjected into $A$. aspersa gives $\mathrm{Ca}^{2+}$ oscillations that are identical to fertilisation. Because of this ascidian offers the best evidence for the physiological relevance of the sperm factor at fertilisation.

The 'content' model proposes that a soluble sperm protein factor is released directly into the egg following gamete fusion (Swann, 1990). This model is based on the finding that soluble extracts from sperm in a number of mammalian and non-mammalian species cause $\mathrm{Ca}^{2+}$ oscillations identical to fertilisation when microinjected into eggs (Swann, 1990; Homa and Swann, 1994; Stricker, 1997; Wu et al., 1997, 1998b; Kyozuka et al., 1998; Tang et al., 2000). The activity of the factor is lost following heat or trypsin treatment. The ascidian egg is the most striking example of how sperm extracts can mimic fertilisation (figure 3) (Kyozuka et al., 1998). Since sperm extracts are able to mimic the fertilisation $\mathrm{Ca}^{2+}$ signal so precisely, we believe the sperm factor theory is the most probable mechanism by which sperm trigger $\mathrm{Ca}^{2+}$ release. Interestingly, most evidence for the existence of a sperm factor comes from species in which a series of $\mathrm{Ca}^{2+}$ oscillations are observed at fertilisation (mammals, ascidians, nemerteans). As yet the significance of this observation is not known.

\section{CANDIDATES FOR THE TITLE OF SPERM FACTOR}

The concept of the sperm factor is not new, being suggested at least 15 years ago (Whitaker and Irvine, 1984) and was first described by Dale et al. (1985) in sea urchin. Since that time the existence of a sea urchin sperm factor has not been the subject of extensive studies, although more recent data suggest that sea urchin sperm do contain a $\mathrm{Ca}^{2+}$-releasing factor that can activate mammalian eggs (Wakayama et al., 1997). Better evidence for a soluble sperm factor has come from the pioneering work of Swann in mammals. Several groups have now reported the existence of 
such a soluble mammalian factor (Wu et al., 1997; Wolosker et al., 1998; Oda et al., 1999; Tang et al., 2000) but its identity remains unknown. The existence of the mammalian sperm factor is based on the ability of soluble extracts to mimic the fertilisation-associated $\mathrm{Ca}^{2+}$ changes (see figure 4 for preparation of extracts). It is well established that the $\mathrm{Ca}^{2+}$-releasing ability of such extracts is lost when extracts are heat- or trypsintreated, suggesting the factor is proteinaceous (Swann, 1990). Furthermore, the active factor can be fractionated using FPLC and this has been the principal method employed for purifying the sperm protein.

A protein, which was named oscillin, isolated from hamster by FPLC was the first proposed sperm factor candidate (Parrington et al., 1996). Oscillin had sequence homology with a bacterial deaminase. It was found exclusively in the equatorial region of the sperm head (Parrington et al., 1996), which is where the sperm fuses with the egg (reviewed in Yanagimachi, 1994). However, further studies from the same group and by others have conclusively shown that oscillin is not the sperm factor. Recombinant oscillin has no $\mathrm{Ca}^{2+}$ releasing ability (Wolosker et al., 1998). Furthermore, fractionated sperm extracts can be obtained which lack any oscillin but still have $\mathrm{Ca}^{2+}$ oscillation-inducing activity (Wu et al., 1998b; Parrington et al., 1999). The opposite is also true. Fractionated extracts which lack oscillin can have $\mathrm{Ca}^{2+}$ oscillation-inducing activity (Wu et al., 1998b; Parrington et al., 1999). The group leading the mammalian sperm factor purification failed to purify the correct protein, a fact that must highlight the difficulties in purifying this protein by FPLC. Obviously fractions which are active at inducing $\mathrm{Ca}^{2+}$ oscillations in mammalian eggs contain a factor which is not readily discernible by SDS-PAGE (figure 1, fractions 4 and 5: Parrington et al., 1996).

Following oscillin there are far more promising candidates that have potential in being the correct sperm factor. A $23-\mathrm{kDa}$ truncated form of the c-kit receptor, which is involved in germ cell migration, termed tr-kit, has been shown to trigger full egg activation following microinjection into mouse eggs. It is specifically expressed late during spermatogenesis and when either tr-kit mRNA or protein is microinjected into eggs all the events of egg activation are induced (Sette et al., 1997). Critically, microinjection of control mRNA or protein fails to induce egg activation. Importantly tr-kit has also been shown to increase $\mathrm{InsP}_{3}$ production by activating PLC $\gamma 1$ (Sette et al., 1998). It may seem trivial that it is still to be shown that tr-kit can induce $\mathrm{Ca}^{2+}$ oscillations when microinjected into eggs. However, it has been demonstrated that sperm extracts which lack tr-kit retain $\mathrm{Ca}^{2+}$ oscillation-inducing activity (Wu et al., 1998b). In fact, tr-kit is localised mainly to the residual body of the sperm mid-piece (Sette et al., 1997) and this region does not activate eggs following micro-

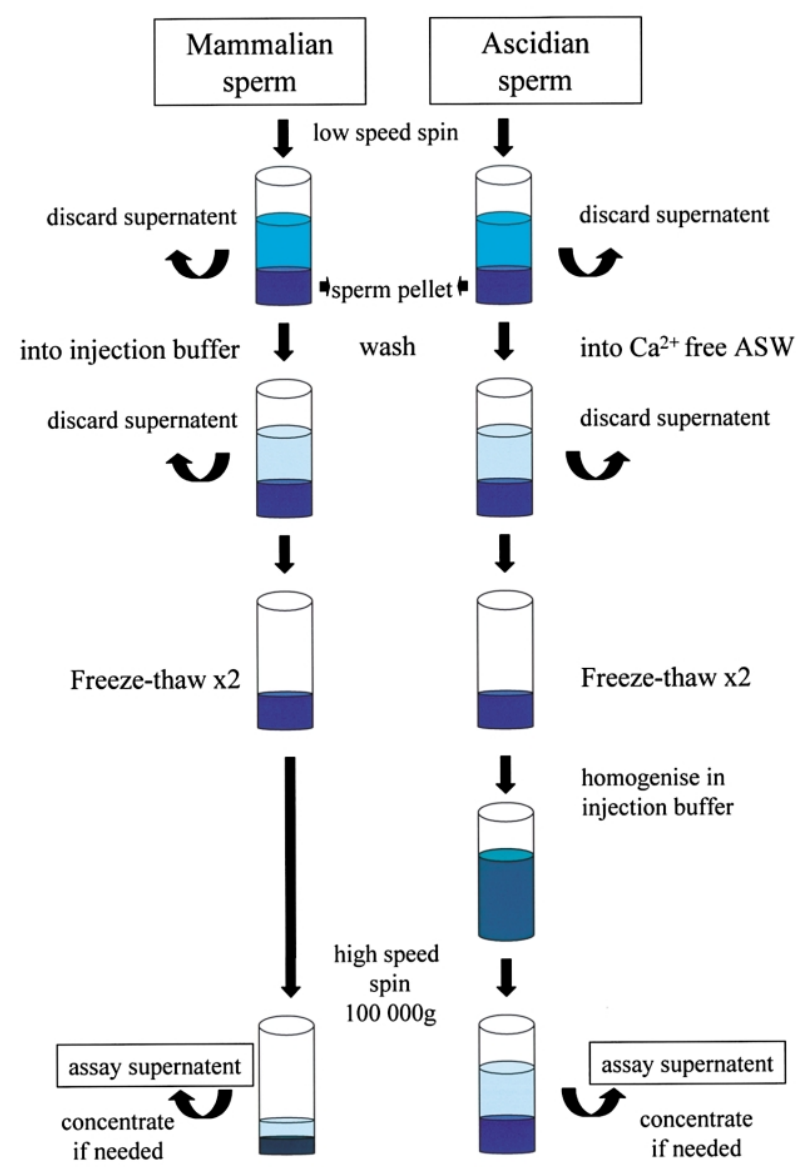

Figure 4. Preparation of mammalian and ascidian sperm extracts. Both mammalian and ascidian sperm extracts are made by a simple protocol. For ascidian sperm we use a freeze-thaw cycle and an homogenisation step to ensure release of the sperm factor (as found by Kyozuka et al., 1998). However, in mammals freezethawing alone is adequate to liberate the $\mathrm{Ca}^{2+}$-releasing factor. To aid protein recovery we suggest the inclusion of protease inhibitors (PMSF and leupeptin). It is necessary to perform all steps at $4^{\circ} \mathrm{C}$ except in mammalian sperm for the initial washes. For more details on preparing mammalian sperm extracts see Swann (1990) and Jones et al. (1998b). A more intricate procedure is described by Kyozuka et al. (1998) for preparing ascidian sperm extracts. Final supernatents may be concentrated on ultrafiltration membranes if found to be very dilute (e.g., Centricons, Amicon, UK).

injection (Kimura et al., 1998). Physiologically tr-kit may actually switch on a sperm PLC rather than an egg PLC, during either spermiation, capacitation or even the acrosome reaction. If the PLC is activated prior to sperm fusion this may explain why $\mathrm{SH} 2$ constructs fail to block fertilisation in the mouse (Mehlmann et al., 1998) but do so in other species (Carroll et al., 1997, 1999; Shearer et al., 1999). SH2 domains 
Table I. Sperm extract equivalents injected into eggs. This table shows the species in which sperm extracts have been injected into eggs and calculations made as to the number of sperm equivalents being introduced. A sperm factor activity has been described in eggs of the protostome clade (Nemertean worms) suggesting it is not limited to animals in the chordate phylum.

\begin{tabular}{lcc}
\hline Animal from which sperm extracts prepared & Sperm extracts mimic fertilisation? & Number of sperm equivalents injected \\
\hline Nemertean worm & Yes & $5.3-20.9^{\mathrm{a}}$ \\
Ascidian & Yes & $1.8^{\mathrm{d}}$ \\
Bovine & Yes & $2-3^{\mathrm{c}, 1}$ \\
Hamster & Yes & $8^{\mathrm{b}, 1}$ \\
Mouse & Yes & $7^{\mathrm{e}, 2} 1-10^{\mathrm{f}}$ \\
\hline
\end{tabular}

\footnotetext{
${ }^{1}$ Sperm extracts were assayed in mouse eggs. ${ }^{2}$ Sperm extract responses were noted as similar to the response seen with polyspermy,

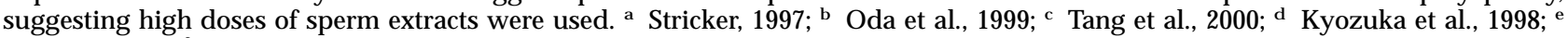
Swann, 1990; f Swann, 1993.
}

block by competing with PLC $\gamma \mathrm{SH} 2$ domains required for PLC activation. If tr-kit were involved in PLC activation in the sperm prior to fertilisation there would be no critical need for tr-kit to be in active fractions. There is good support for a model in which tr-kit induces activation of a sperm PLC since sperm do contain active PLC (Jones et al., 1998b). Following FPLC of sperm extracts this sperm PLC activity remains associated with fractions capable of inducing $\mathrm{Ca}^{2+}$ oscillations when microinjected into mouse eggs (Parrington et al., 1999). At present it is not known if the sperm PLC is a member of the PLC $\gamma, \operatorname{PLC} \beta$ or PLCo family.

\section{ARGUMENTS AGAINST THE SOLUBLE SPERM FACTOR THEORY}

Does the soluble sperm factor act alone at fertilisation in activating the egg? While it is clear that a soluble sperm factor is able to induce all the events associated with egg activation (Stice and Robl, 1990; $\mathrm{Wu}$ et al., 1998a), it could be argued that multiple mechanisms operate to ensure activation. At this stage it is not possible to rule out this scenario. Non-soluble perinuclear material from mouse sperm heads can cause $\mathrm{Ca}^{2+}$ oscillations (and so egg activation) when microinjected into eggs (Perry et al., 2000). Although we favour this as evidence that in the mouse the sperm factor is not entirely soluble, Perry et al. (2000) suggest that there are multiple sperm components (so-called SOAF-Is in combination with SOAF-II). This supposition is based on their ability to recombine 'inactive' fractions to produce an active one (Perry et al., 2000). At this stage it is not entirely clear whether such an effect could be attributed to dose alone. Until the identity of these components are known little can be said about their merit. The more obvious sperm factor candidate is the one that is extractable (in the most part) and which causes full egg activation, as established by a number of independent groups.
Once the sperm factor has been identified, either a mouse knockout or an immunoprecipitating/ functionally inhibitory antibody may go someway to addressing the above point. Alternatively, in the meantime it is possible that an egg receptor/sperm ligand interaction will be found that complements the action of the sperm factor.

Another important issue is the amount of sperm extracts being injected into eggs. Could it be that a high number of sperm equivalents are being microinjected such that we are observing a non-physiological phenomenon? Table I highlights the calculated sperm equivalents injected to induce $\mathrm{Ca}^{2+}$ oscillations for various species. These sperm equivalents are not high. It must be noted that incomplete recovery of the sperm factor from sperm and loss of activity of the sperm factor with time are two parameters not easily quantified. Therefore it would be highly unlikely to recover $100 \%$ sperm factor activity and maintain $100 \%$ activity in the extracts.

\section{CALCIUM AND THE CELL CYCLE}

We have addressed how the sperm probably initiates $\mathrm{Ca}^{2+}$ release, but once initiated how are the $\mathrm{Ca}^{2+}$ oscillations controlled? In mammals it seems probable that long-lasting $\mathrm{Ca}^{2+}$ oscillations ensure exit from meiosis. If freshly ovulated MII eggs are treated with ethanol, to induce a $\mathrm{Ca}^{2+}$ transient, then the eggs start to activate. They extrude a second polar body but then the egg re-arrests at metaphase (in a so-called MIII state) (Kubiak, 1989). Thus MPF activity comes back. MPF similarly returns in eggs given a single $\mathrm{Ca}^{2+}$ transient through electrical activation (Collas et al., 1993, 1995). Therefore, without a long-lasting series of $\mathrm{Ca}^{2+}$ oscillations the egg does not escape meiosis. It is certainly the case that eggs can be fully activated by a single $\mathrm{Ca}^{2+}$ transient or without $\mathrm{Ca}^{2+}$ at all (Whittingham, 1980). However, this is usually so in eggs that are aged and have passed the window in which they are 
normally fertilised. Protein synthesis inhibitors and agents that cause a monotonic $\mathrm{Ca}^{2+}$ rise are very effective activating agents in aged eggs (Whittingham, 1980 and references therein). Thus with age it is presumed that the ability of the egg to maintain MPF and CSF activity declines. Obviously if MPF and CSF activity decline below a threshold necessary to keep the egg arrested, then activation will ensue, independent of any $\mathrm{Ca}^{2+}$ signal.

The influence that cell cycle resumption has on mammalian eggs is seen in the finding that $\mathrm{Ca}^{2+}$ oscillations stop around the time that pronuclei form in the newly formed zygote (Jones et al., 1995; Deguchi et al., 2000). Interestingly, Parrington et al. (1998) and He et al. (1999) both reported that the type $1 \mathrm{InsP}_{3}$ receptor is down-regulated following fertilisation. Such a down-regulation in receptor number requires $\mathrm{InsP}_{3}$ binding to its receptor (Zhu et al., 1999). This provides further support to the suggestion that a PLC (sperm or egg) generates $\mathrm{InsP}_{3}$ at fertilisation and also may give us a simple model to explain the cessation of $\mathrm{Ca}^{2+}$ oscillations. Simply, $\mathrm{Ca}^{2+}$ oscillations stop when the $\mathrm{InsP}_{3}$ receptor has been critically down-regulated. However, if meiotic progression is blocked by disrupting the integrity of the metaphase spindle (spindle checkpoint) using microtubule disrupting agents and the egg remains locked in meiosis, then $\mathrm{Ca}^{2+}$ oscillations continue indefinitely (Jones et al., 1995). Pronuclei are formed by $6 \mathrm{~h}$ following sperm addition in control eggs whilst in colcemid-treated eggs no pronuclei form and we can observe $\mathrm{Ca}^{2+}$ oscillations continuing some $18 \mathrm{~h}$ post fertilisation. It is possible that the downregulation of the $\mathrm{InsP}_{3}$ receptor is blocked in colcemidtreated eggs or alternatively that cell cycle components are involved in maintaining/stopping the $\mathrm{Ca}^{2+}$ oscillations. In support of a cell cycle component, zygotes during interphase do not show $\mathrm{Ca}^{2+}$ oscillations but do when they undergo entry into first mitosis (Tombes et al., 1992; Kono et al., 1996). Furthermore, $\mathrm{Ca}^{2+}$ oscillations have been reported to last the entire period of M-phase (Kono et al., 1996). Therefore, it is suggested that the sperm factor (still present in the zygote from fertilisation) may be reactivated by factors present in the mitotic embryo, which are common to meiosis. Candidates that could induce reactivation include MPF and MAP kinase. Very recent evidence (Deng and Shen, 2000) shows that roscovitine, an inhibitor of MPF activity, can reversibly block fertilisation-associated $\mathrm{Ca}^{2+}$ changes in mouse eggs, implying that a high MPF activity is needed to maintain $\mathrm{Ca}^{2+}$ oscillations.

In the ascidian there is very good evidence that cyclin B1-dependent kinase, the principal kinase component of MPF, controls the pattern of $\mathrm{Ca}^{2+}$ release at fertilisation. This is based on the observation that sperm-triggered $\mathrm{Ca}^{2+}$ oscillations do not stop in a background of elevated MPF and low MAP kinase activity (Levasseur and McDougall, 2000). The straightforward conclusion to be drawn from these data is that the MPF activity of the fertilised egg positively regulates the $\mathrm{Ca}^{2+}$ oscillations. The molecular details of how MPF accomplishes this task are not yet known. There are, however, two main possibilities that encompass most (perhaps all) of the specific ideas. These are that the MPF activity could affect the $\mathrm{Ca}^{2+}$ signalling system of the egg or that the MPF activity could affect the sperm factor. The first of these two hypotheses has been tested. Although there is evidence that the $\mathrm{Ca}^{2+}$ signalling system desensitises as the ascidian egg exits meiosis (McDougall and Levasseur, 1998), it is noteworthy that the desensitisation of the $\mathrm{InsP}_{3}$ receptor does not completely follow the same temporal profile of the MPF activity. This was shown in the observation that the $\mathrm{InsP}_{3}$ receptor remains sensitive during the period when the first polar body is extruded and the MPF activity is low (McDougall and Levasseur, 1998). Although these data are a useful indicator to distinguish between the two main possibilities noted above, they are not conclusive since the sensitivity of the $\mathrm{InsP}_{3}$ receptors in the $\mathrm{Ca}^{2+}$ wave pacemaker was not measured. However, the observations that adenophostin B, a non-metabolisable agonist of the $\mathrm{InsP}_{3}$ receptor, gives one long series of $\mathrm{Ca}^{2+}$ oscillations without a noticeable alteration in frequency (Yoshida et al., 1998), also suggest that the sensitivity of the $\mathrm{Ca}^{2+}$ signalling system does not completely follow the activity of MPF. Adenophostin B may be useful to determine the sensitivity of the $\mathrm{InsP}_{3}$ receptor since the frequency of the $\mathrm{Ca}^{2+}$ oscillations triggered by adenophostin B decreased approximately $25 \mathrm{~min}$ following injection, at the time the sperm-triggered $\mathrm{Ca}^{2+}$ oscillations would normally stop (Yoshida et al., 1998). This is likely to indicate the desensitisation of $\mathrm{Ca}^{2+}$ signalling system that accompanies meiotic exit (McDougall and Levasseur, 1998). Although there are indications that the $\mathrm{Ca}^{2+}$ signalling system does not completely follow the activity of MPF, we still do not know for certain whether the MPF activity affects the $\mathrm{Ca}^{2+}$ signalling system or the sperm factor protein in fertilised ascidian eggs. To further test between the possibilities, it will be useful to examine the sensitivity of the $\mathrm{Ca}^{2+}$ signalling system in fertilised eggs that contain persistently elevated MPF activity.

\section{CONCLUSION}

This review has concentrated on the role of $\mathrm{Ca}^{2+}$ at fertilisation. We argue strongly that a sperm-borne $\mathrm{Ca}^{2+}$-releasing factor is released into the egg following gamete fusion and it is most likely a PLC or else a PLC activator. The $\mathrm{Ca}^{2+}$ oscillations observed in both mammalian and ascidian eggs at fertilisation seem regulated by cell cycle factors. The relationship between the 
cell cycle and $\mathrm{Ca}^{2+}$ oscillations at fertilisation may only be fully understood once we have identified the sperm factor.

Acknowledgments. The authors would like to express thanks to John Parrington and Karl Swann for helpful discussion during the preparation of this review. Alex McDougall and Keith Jones both currently hold Wellcome Trust funded research projects and acknowledge the Trust's continued support.

\section{REFERENCES}

Arnoult, C., Grunwald, D., Villaz, M., 1996. Novel postfertilization inward $\mathrm{Ca}^{2+}$ current in ascidian eggs ensuring a calcium entry throughout meiosis. Dev. Biol. 174, 322-334.

Ben-Yosef, D., Oron, Y., Shalgi, R., 1993. Prolonged, repetitive calcium transients in rat oocytes fertilized in vitro and in vivo. FEBS Lett. 331, 239-242.

Busa, W.B., Nuccitelli, R., 1985. An elevated free cytosolic $\mathrm{Ca}^{2+}$ wave follows fertilization in eggs of the frog, Xenopus laevis. J. Cell Biol. 100, 1325-1329.

Carroll, D.J., Ramarao, C.S., Mehlmann, L.M., Roche, S., Terasaki, M., Jaffe, L.A., 1997. Calcium release at fertilization in starfish eggs is mediated by phospholipase C. J. Cell Biol. 138, 1303-1311.

Carroll, D.J., Albay, D.T., Terasaki, M., Jaffe, L.A., Foltz, K.R., 1999. Identification of PLC-dependent and -independent events during fertilization of sea urchin eggs. Dev. Biol. 206, 232-247.

Cho, C., Bunch, D.O., Faure, J.E., Goulding, E.H., Eddy, E.M., Primakoff, P., Myles, D.G., 1998. Fertilization defects in sperm from mice lacking fertilin beta. Science 281, 1857-1859.

Ciemerych, M.A., Kubiak, J.Z., 1999. Transient reactivation of CSF in parthenogenetic one-cell mouse embryos. Biol. Cell 91, 641-647.

Collas, P., Sullivan, E.J., Barnes, F.L., 1993. Histone H1 kinase activity in bovine oocytes following calcium stimulation. Mol. Reprod. Dev. 34, 224-231.

Collas, P., Chang, T., Long, C., Robl, J.M., 1995. Inactivation of histone H1 kinase by calcium in rabbit oocytes. Mol. Reprod. Dev. 40, 253-258.

Colledge, W.H., Carlton, M.B.L., Udy, G.B., Evans, M.J., 1994. Disruption of c-mos causes parthenogenetic development of unfertilized mouse eggs. Nature 370, 65-67.

Creton, R., Jaffe, L.F., 1995. Role of calcium influx during the latent period in sea urchin fertilization. Dev. Growth Differ. 37, 703-709.

Cuthbertson, K.S., Cobbold, P.H., 1985. Phorbol ester and sperm activate mouse oocytes by inducing sustained oscillations in cell $\mathrm{Ca}^{2+}$. Nature 316, 541-542.

Dale, B., Defelice, L.J., Ehrenstein, G., 1985. Injection of a soluble sperm fraction into sea-urchin eggs triggers the cortical reaction. Experimentia 41, 1068-1070.

Deguchi, R., Shirakawa, H., Oda, S., Mohri, T., Miyazaki, S., 2000. Spatiotemporal analysis of the calcium waves in relation to the sperm entry site and animal-vegetal axis during calcium oscillations in fertilized mouse eggs. Dev. Biol. 218, 299-313.

Deng, M.Q., Shen, S.S., 2000. A specific inhibitor of p34cdc/cyclin B suppresses fertilization-induced calcium oscillations in mouse eggs. Biol. Reprod. 62, 873-878.

Digonnet, C., Aldon, D., Leduc, N., Dumas, C., Rougier, M., 1997. First evidence of a calcium transient in flowering plants at fertilization. Development 124, 2867-2874.

Ducibella, T., Kurasawa, S., Duffy, P., Kopf, G.S., Schultz, R.M., 1993. Regulation of the polyspermy block in the mouse egg: maturationdependent differences in cortical granule exocytosis and zona pellucida modifications induced by inositol 1,4,5-trisphosphate and an activator of protein kinase C. Biol. Reprod. 48, 1251-1257.
Dunphy, W.G., Brizuela, L., Beach, D., Newport, J., 1988. The Xenopus cdc2 protein is a component of MPF, a cytoplasmic regulator of mitosis. Cell 54, 423-431.

Dupont, G., McGuinness, O.M., Johnson, M.H., Berridge, M.J., Borgese, F., 1996. Phospholipase $C$ in mouse oocytes: characterization of $\beta$ and $\gamma$ isoforms and their possible involvement in sperm-induced $\mathrm{Ca}^{2+}$ spiking. Biochem. J. 316, 583-591.

Evans, J.P., Kopf, G.S., 1998. Molecular mechanisms of sperm-egg interactions and egg activation. Andrologia 30, 297-307.

Evans, T., Rosenthal, E.T., Youngblom, J., Distel, D., Hunt, T., 1983. Cyclin: a protein specified by maternal mRNA in sea urchin eggs that is destroyed at each cleavage division. Cell 33, 389-396.

Fabiato, A., 1985. Spontaneous versus triggered contractions of 'calcium-tolerant' cardiac cells from the adult rat ventricle. Basic Res. Cardiol. 80, 83-87.

Fissore, R.A., Robl, J.M., 1993. Sperm, inositol trisphosphate, and thimerosal-induced intracellular $\mathrm{Ca}^{2+}$ elevations in rabbit eggs. Dev. Biol. 159, 122-130.

Fissore, R.A., Dobrinsky, J.R., Balise, J.J., Duby, R.T., Robl, J.M., 1992. Patterns of intracellular $\mathrm{Ca}^{2+}$ concentrations in fertilized bovine eggs. Biol. Reprod. 47, 960-969.

Foltz, K.R., Shilling, F.M., 1993. Receptor-mediated signal transduction and egg activation. Zygote 1, 276-279.

Fulton, B.P., Whittingham, D.G., 1978. Activation of mammalian oocytes by intracellular injection of calcium. Nature 273, 149-151.

Gautier, J., Norbury, C., Lohka, M., Nurse, P., Maller, J., 1988. Purified maturation-promoting factor contains the product of a Xenopus homolog of the fission yeast cell cycle control gene cdc2. Cell 54, 433-439.

Goudeau, M., Goudeau, H., 1996. External $\mathrm{Mg}^{2+}$ triggers oscillations and a subsequent sustained level intracellular free $\mathrm{Ca}^{2+}$, correlated with changes in membrane conductance in the oocyte of the prawn Palaemon serratus. Dev. Biol. 177, 178-189.

Goudeau, H., Depresle, Y., Rosa, A., Goudeau, M., 1994. Evidence by a voltage clamp study of an electrically-mediated block to polyspermy in the egg of the ascidian Phallusia maammillata. Dev. Biol. 166, 489-501.

Hashimoto, N., Watanabe, N., Furuta, Y., Tamemoto, H., Sagata, N., Yokoyama, M., Okazaki, K., Nagayoshi, M., Takeda, N., Aizawa, S., 1994. Parthenogenetic activation of oocytes in c-mos-deficient mice. Nature 370, 68-71.

He, C.L., Damiani, P., Ducibella, T., Takahashi, M., Tanzawa, K., Parys, J.B., Fissore, R.A., 1999. Isoforms of the inositol 1,4,5-trisphosphate receptor are expressed in bovine oocytes and ovaries: the type-1 isoform is down-regulated by fertilization and by injection of adenophostin A. Biol. Reprod. 61, 935-943.

Homa, S.T., Swann, K., 1994. A cytosolic sperm factor triggers calcium oscillations and membrane hyperpolarizations in human oocytes. Hum. Reprod. 9, 2356-2361.

Igusa, Y., Miyazaki, S., 1983. Effects of altered extracellular and intracellular calcium concentrations on hyperpolarizing responses of the hamster egg. J. Physiol. 340, 611-632.

Inagaki, N., Suzuki, S., Kitai, H., Nakatogawa, N., Kuji, N., Iwahashi, K., Yoshimura, Y., 1997. Effect of $\mathrm{KN}-62$, a selective inhibitor of calmodulin-dependent kinase II, on mouse oocyte activation. J. Assist. Reprod. Gen. 14, 609-616.

Jaffe, L.F., 1991. The path of calcium in cytosolic calcium oscillations: a unifying hypothesis. Proc. Natl. Acad. Sci. USA 88, 9883-9887.

Jones, K.T., 1998. $\mathrm{Ca}^{2+}$ oscillations in the activation of the egg and development of the embryo in mammals. Int. J. Dev. Biol. 42, 1-10.

Jones, K.T., Whittingham, D.G., 1996. A comparison of sperm- and IP3-induced $\mathrm{Ca}^{2+}$ release in activated and aging mouse oocytes. Dev. Biol. 178, 229-237.

Jones, K.T., Carroll, J., Merriman, J.A., Whittingham, D.G., Kono, T., 1995. Repetitive sperm-induced $\mathrm{Ca}^{2+}$ transients in mouse oocytes are cell cycle dependent. Development 121, 3259-3266.

Jones, K.T., Soeller, C., Cannell, M.B., 1998a. The passage of $\mathrm{Ca}^{2+}$ and fluorescent markers between the sperm and egg after fusion in the mouse. Development 125, 4627-4635. 
Jones, K.T., Cruttwell, C., Parrington, J., Swann, K., 1998b. A mammalian sperm cytosolic phospholipase $\mathrm{C}$ activity generates inositol trisphosphate and causes $\mathrm{Ca}^{2+}$ release in sea urchin egg homogenates. FEBS Lett. 437, 297-300.

Kimura, Y., Yanagimachi, R., Kuretake, S., Bortkiewicz, H., Perry, A.C.F., Yanagimachi, H., 1998. Analysis of mouse oocyte activation suggests the involvement of sperm perinuclear material. Biol. Reprod. 58, 1407-1415.

Kline, D., Kline, J.T., 1992. Repetitive calcium transients and the role of calcium in exocytosis and cell-cycle activation in the mouse egg. Dev. Biol. 149, 80-89.

Kline, D., Mehlmann, L., Fox, C., Terasaki, M., 1999. The cortical endoplasmic reticulum (ER) of the mouse egg: Localisation of ER clusters in relation to the generation of the repetitive $\mathrm{Ca}^{2+}$ waves. Dev. Biol. 215, 431-442.

Kono, T., Jones, K.T., Bos-Mikich, A., Whittingham, D.G., Carroll, J., 1996. A cell cycle associated change in $\mathrm{Ca}^{2+}$ releasing activity leads to the generation of $\mathrm{Ca}^{2+}$ transients in mouse embryos during the first meiotic division. J. Cell Biol. 132, 915-923.

Kubiak, J.Z., 1989. Mouse oocytes gradually develop the capacity for activation during the metaphase II arrest. Dev. Biol. 136, 537-545.

Kyozuka, K., Deguchi, R., Mohri, T., Miyazaki, S., 1998. Injection of sperm extract mimics spatiotemporal dynamics of $\mathrm{Ca}^{2+}$ responses and progression of meiosis at fertilization of ascidian oocytes. Development 125, 4099-4105.

Labbe, J.C., Capony, J.P., Caput, D., Cavadore, J., Derancourt, M., Kaghad, M., Lelias, J.M., Picard, A., Doree, M., 1989. MPF from starfish oocytes at first meiotic metaphase is a heterodimer containing one molecule of cdc2 and one molecule of cyclin B. EMBO J. 8 , 3053-3058.

Lambert, C.C., 1989. Ascidian eggs release glycosidase activity which aids in the block against polyspermy. Development 105, 415-420.

Lee, K.W., Webb, S.E., Miller, A.L., 1999. A wave of free cytosolic calcium traverses zebrafish eggs on activation. Dev. Biol. 214, $168-180$.

LeNaour, F., Rubinstein, E., Jasmin, C., Prenant, M., Boucheix, N., 2000. Severely reduced female fertility in CD9-deficient mice. Science 287, 319-321.

Levasseur, M., McDougall, A., 2000. Sperm-induced calcium oscillations at fertilisation in ascidians are controlled by cyclin B1dependent kinase activity. Development 127, 631-641.

Lindsay, L.L., Hertzler, P.L., Clarke, W.H.J., 1992. Extracellular $\mathrm{Mg}^{2+}$ induces an intracellular $\mathrm{Ca}^{2+}$ wave during oocyte activation in the marine shrimp Sicyonia ingentis. Dev. Biol. 152, 94-102.

Lohka, M.J., Hayes, M.K., Maller, J.L., 1988. Purification of maturationpromoting factor, an intracellular regulator of early mitotic events. Proc. Natl. Acad. Sci. USA 85, 3009-3013.

Lorca, T., Cruzalegui, F.H., Fesquet, D., Cavadore, J.C., Mery, J., Means, A., Doree, M., 1993. Calmodulin-dependent protein kinase II mediates inactivation of MPF and CSF upon fertilization of Xenopus eggs. Nature 366, 270-273.

Masui, Y., 1974. A cytostatic factor in amphibian oocytes: its extraction and partial characterisation. J. Exp. Zool. 187, 141-147.

Masui, Y., 1991. The role of 'cytostatic factor (CSF)' in the control of oocyte cell cycles: A summary of 20 years of study. Dev. Growth Differ. 33, 543-551.

Masui, Y., Markert, C.L., 1971. Cytoplasmic control of nuclear behaviour during meiotic maturation of frog oocytes. J. Exp. Zool. 177, 129-145.

McDougall, A., Levasseur, M., 1998. Sperm-triggered calcium oscillations during meiosis in ascidian oocytes first pause, then stop: correlations with cell cycle kinase activity. Development 125, 4451-4459.

McDougall, A., Sardet, N., 1995. Function and characteristics of repetitive calcium waves associated with meiosis. Curr. Biol. 5, 318-328.

McDougall, A., Sardet, C., Lambert, C.C., 1995. Different calciumdependent pathways control fertilisation-triggered glycosidase release and the cortical contraction in ascidian eggs. Zygote 3, 251-258.
McGuinness, O.M., Moreton, R.B., Johnson, M.H., Berridge, M.J., 1996. A direct measurement of increased divalent cation influx in fertilised mouse oocytes. Development 122, 2199-2206.

Mehlmann, L.M., Carpenter, G., Rhee, S.G., Jaffe, L.A., 1998. SH2 domain-mediated activation of phospholipase $C$ is not required to initiate $\mathrm{Ca}^{2+}$ release at fertilization of mouse eggs. Dev. Biol. 203, 221-232.

Miyado, K., Yamada, G., Yamada, S., Hasuwa, H., Nakamura, Y., Ryu, F., Suzuki, K., Kosai, K., Inoue, K., Ogura, A., Okabe, M., Mekeda, E., 2000. Requirement of CD9 on the egg plasma membrane for fertilization. Science 287, 321-324.

Miyazaki, S., Igusa, Y., 1981. Fertilization potential in golden hamster eggs consists of recurring hyperpolarizations. Nature 290, 702-704.

Miyazaki, S., Hashimoto, N., Yoshimoto, Y., Kishimoto, T., Igusa, Y., Hiramoto, Y., 1986. Temporal and spatial dynamics of the periodic increase in intracellular free calcium at fertilisation of golden hamster eggs. Dev. Biol. 118, 259-267.

Miyazaki, S., Yuzaki, M., Nakada, K., Shirakawa, H., Nakanishi, S., Nakade, S., Mokoshiba, K., 1992. Block of $\mathrm{Ca}^{2+}$ wave and $\mathrm{Ca}^{2+}$ oscillation by antibody to the inositol 1,4,5-trisphosphate receptor in fertilized hamster eggs. Science 257, 251-255.

Miyazaki, S., Shirakawa, H., Nakada, K., Honda, Y., 1993. Essential role of the inositol 1,4,5-trisphosphate receptor $/ \mathrm{Ca}^{2+}$ release channel in $\mathrm{Ca}^{2+}$ waves and $\mathrm{Ca}^{2+}$ oscillations at fertilization of mammalian egg. Dev. Biol. 158, 62-78.

Morgan, D.O., 1997. Cyclin-dependent kinases: Engines, clocks, and microprocessors. Annu. Rev. Cell Dev. Biol. 13, 261-291.

Murray, A.W., Solomon, M.J., Kirschner, M.W., 1989. The role of cyclin synthesis and degradation in the control of maturation promotion factor activity. Nature 339, 280-286.

Nurse, P., 1990. Universal control mechanism regulating onset of M-phase. Nature 344, 503-508.

Nurse, P., Thuriaux, P., 1980. Regulatory genes controlling mitosis in the fission yeast Schizosaccharomyces pombe. Genetics 96, 627-637.

Oda, S., Deguchi, R., Mohri, T., Shikano, T., Nakanishi, S., Miyazaki, S., 1999. Spatiotemporal dynamics of the $\left[\mathrm{Ca}^{2+}\right]_{\mathrm{i}}$ rise induced by microinjection of sperm extract into mouse eggs: preferential induction of $\mathrm{a} \mathrm{Ca}^{2+}$ wave from the cortex mediated by the inositol 1,4,5-trisphosphate receptor. Dev. Biol. 209, 172-185.

Parrington, J., Swann, K., Shevchenko, V.I., Sesay, A.K., Lai, F.A., 1996. Calcium oscillations in mammalian eggs triggered by a soluble sperm protein. Nature 379, 364-368.

Parrington, J., Brind, S., De Smedt, H., Gangeswaran, R., Lai, F.A., Wojcikiewicz, R., Carroll, J., 1998. Expression of inositol 1,4,5trisphosphate receptors in mouse oocytes and early embryos: the type 1 isoform is upregulated in oocytes and downregulated after fertilisation. Dev. Biol. 203, 451-461.

Parrington, J., Jones, K.T., Lai, F.A., Swann, K., 1999. The soluble sperm factor that causes $\mathrm{Ca}^{2+}$ release from sea-urchin (lytechinus pictus) egg homogenates also triggers $\mathrm{Ca}^{2+}$ oscillations after injection into mouse eggs. Biochem. J. 341, 1-4.

Perry, A.C.F., Wakayama, T., Cooke, I.M., Yanagimachi, R., 2000. Mammalian oocyte activation by the synergistic action of discrete sperm head components: induction of calcium transients and involvement of proteolysis. Dev. Biol. 217, 386-393.

Ridgway, E.B., Gilkey, J.C., Jaffe, L.F., 1977. Free calcium increases explosively in activating medaka eggs. Proc. Natl. Acad. Sci. USA 74, 623-627.

Robert, L.K., Lucio-Gough, L.M., Goode, C.A., McKinney, K., Lambert, C.C., 1999. Activation of follicle cell surface phospholipace by tyrosine kinase dependent pathway is an essential event in ascidian fertilisation. Mol. Reprod. Dev. 54, 69-75.

Russo, G.L., Kyozuka, K., Antonazzo, L., Tosti, E., Dale, B., 1996. Maturation promoting factor in ascidian oocytes is regulated by different intracellular signals at meiosis I and II. Development 122, 1995-2003.

Sagata, N., 1997. What does Mos do in oocytes and somatic cells?. BioEssays 19, 13-21. 
Sette, C., Bevilacqua, A., Bianchini, A., Mangia, F., Geremia, R., Rossi, P., 1997. Parthenogenetic activation of mouse eggs by microinjection of a truncated c-kit tyrosine kinase present in spermatozoa. Development 124, 2267-2274.

Sette, C., Bevilacqua, A., Geremia, R., Rossi, P., 1998. Involvement of phospholipase 1 in mouse egg activation induced by a truncated form of the c-kit tyrosine kinase present in spermatozoa. J. Cell Biol. 142, 1063-1074.

Shearer, J., De Nadai, C., Emily-Fenouil, F., Gache, C., Whitaker, M., Ciapa, B., 1999. Role of phospholipase C (gamma) at fertilization and during mitosis in sea urchin eggs and embryos. Development 126, 2273-2284.

Smith, L.D., Ecker, R.E., 1971. The interaction of steroids with Rana pipiens oocytes in the induction of maturation. Dev. Biol. 25, 233-247.

Speksnijder, J.E., Jaffe, L.F., Sardet, C., 1989a. Polarity of sperm entry in the ascidian egg. Dev. Biol. 133, 180-184.

Speksnijder, J.E., Corson, W., Sardet, C., Jaffe, L.F., 1989b. Free Ca ${ }^{2+}$ pulses follow fertilization in the ascidian egg. Dev. Biol. 135, 182-190.

Steinhardt, R., Zucker, R., Schatten, G., 1977. Intracellular calcium release at fertilization in the sea urchin egg. Dev. Biol. 58, 185-196.

Stice, S.L., Robl, J.M., 1990. Activation of mammalian oocytes by a factor obtained from rabbit sperm. Mol. Reprod. Dev. 25, 272-280.

Stricker, S.A., 1997. Intracellular injections of a soluble sperm factor trigger calcium oscillations and meiotic maturation in unfertilized oocytes from a marine worm. Dev. Biol. 186, 185-201.

Sun, F.Z., Hoyland, J., Huang, X., Mason, W., Moor, R.M., 1992. A comparison of intracellular changes in porcine eggs after fertilization and electroactivation. Development 115, 947-956.

Swann, K., 1990. A cytosolic sperm factor stimulates repetitive calcium increases and mimics fertilization in hamster eggs. Development $110,1295-1302$.

Swann, K., 1993. The soluble sperm oscillogen hypothesis. Zygote 1, 273-279.

Swann, K., 1994. $\mathrm{Ca}^{2+}$ oscillations and sensitization of $\mathrm{Ca}^{2+}$ release in unfertilized mouse eggs injected with a sperm factor. Cell Calcium $15,331-339$

Swann, K., Igusa, Y., Miyazaki, S., 1989. Evidence for an inhibitory effect of protein kinase $\mathrm{C}$ on G-protein-mediated repetitive calcium transients in hamster eggs. EMBO J. 8, 3711-3718.

Tang, T.S., Dong, J.B., Huang, X.Y., Sun, F.Z., 2000. $\mathrm{Ca}^{2+}$ oscillations induced by a cytosolic sperm protein factors are mediated by a maternal machinery that functions only once in mammalian eggs. Development 127, 1141-1150.

Tatone, C., Iorio, R., Francione, A., Gioia, L., Colonna, R., 1999. Biochemical and biological effects of $\mathrm{KN}-93$, an inhibitor of calmodulin-dependent protein kinase II, on the initial events of mouse egg activation induced by ethanol. J. Reprod. Fert. 115, $151-157$.
Taylor, C.T., Lawrence, Y.M., Kingsland, C.R., Biljan, M.M., Cuthbertson, K.S., 1993. Oscillations in intracellular free calcium induced by spermatozoa in human oocytes at fertilization. Hum. Reprod. 8, 2174-2179.

Tombes, R.M., Simerly, C., Borisy, G.G., Schatten, G., 1992. Meiosis, egg activation, and nuclear envelope breakdown are differentially reliant on $\mathrm{Ca}^{2+}$, whereas germinal vesicle breakdown is $\mathrm{Ca}^{2+}$ independent in the mouse oocyte. J. Cell. Biol. 117, 799-811.

Wakayama, T., Uehara, T., Hayashi, Y., Yanagimachi, R., 1997. The response of mouse oocytes injected with sea urchin sperm. Zygote 5 , 229-234.

Whitaker, M., 1996. Control of meiotic arrest. Rev. Reprod. 1, 127-135.

Whitaker, M., Irvine, R.F., 1984. Inositol 1,4,5-trisphosphate microinjection activates sea-urchin eggs. Nature 312, 636-639.

Whittingham, D.G., 1980. Parthenogenesis in mammals. In: Finn, C.A. (Ed.), Oxford Reviews in Reproductive Biology Volume 2. Oxford University Press, Oxford, pp. 205-231.

Wier, W.G., Blatter, L.A., 1991. Ca(2+)-oscillations and $\mathrm{Ca}(2+)$-waves in mammalian cardiac and vascular smooth muscle cells. Cell Calcium $12,241-254$

Winston, N.J., Maro, B., 1995. Calmodulin-dependent protein kinase II is activated transiently in ethanol-stimulated mouse oocytes. Dev. Biol. 170, 350-352.

Wolosker, H., Kline, D., Bian, Y., Blackshaw, S., Cameron, M., Fralich, T.J., Schnaar, R.L., Snyder, S.H., 1998. Molecularly cloned mammalian glucosamine-6-phosphate deaminase localizes to transporting epithelium and lacks oscillin activity. FASEB J 12, 91-99.

$\mathrm{Wu}, \mathrm{H} ., \mathrm{He}, \mathrm{C} . \mathrm{L} .$, Fissore, R.A., 1997. Injection of a porcine sperm factor triggers calcium oscillations in mouse oocytes and bovine eggs. Mol. Reprod. Dev. 46, 176-189.

Wu, H., He, C.L., Fissore, R.A., 1998a. Injection of porcine sperm factor induces activation of mouse eggs. Mol. Reprod. Dev. 49, 37-47.

Wu, H., He, C.L., Jehn, B., Black, S.J., Fissore, R.A., 1998b. Partial characterization of the calcium-releasing activity of porcine sperm cytosolic extracts. Dev. Biol. 203, 369-381.

Xu, Z., Kopf, G.S., Schultz, R.M., 1994. Involvement of inositol 1,4,5trisphosphate-mediated $\mathrm{Ca}^{2+}$ release in early and late events of mouse egg activation. Development 120, 1852-1859.

Yanagimachi, R., 1994. Mammalian fertilization. In: Knobil, E., Neill, J.D. (Eds.), The Physiology of Reproduction, Second Series. Raven Press, Ltd., New York, pp. 189-317.

Yoshida, M., Sensui, N., Inoue, T., Morisawa, M., Mikoshiba, K., 1998. Role of two series of $\mathrm{Ca}^{2+}$ oscillations in activated ascidian eggs. Dev. Biol. 203, 122-133.

Zhu, C.C., Furuichi, T., Mikoshiba, K., Wojcikiewicz, R.J.H., 1999. Inositol 1,4,5-trisphosphate receptor down-regulation is activated directly aby inositol 1,4,5-trisphosphate binding. J. Biol. Chem. 274, 3476-3484. 